\title{
Effect of some growth stimulants on production and quality of strawberry transplants
}

\author{
Mohamed, M. H. M. \\ Hort. Dept., Faculty of Agric., Benha Univ., Egypt \\ Corresponding author: mustafa.mohamed@farg.bu.edu.eg.
}

\begin{abstract}
This study was undertaken during the two successive seasons of 2013 and 2014 under sandy soil conditions at private Sector Farm at Kafr Elsohbi Village, Shibin Elqantar, Qalubia Governorate Egypt, to study the effect of using some growth stimulants treatments, i.e., humic acid at $5 \mathrm{~g} /$ plant, seaweed extract at $5 \mathrm{ml} / \mathrm{plant}$, compost tea at $10 \mathrm{ml} /$ plant and effective microorganisms (EM) at $5 \mathrm{ml} /$ plant through soil application and amino acids at $2 \mathrm{ml} / \mathrm{l}$, seaweed extract at $2 \mathrm{ml} / 1$ and gibberellic acid at $50 \mathrm{ppm}$ as a foliar spray and their interactions on growth, chemical compostion, production and quality of strawberry transplants cv. Festival. The obtained results showed that the highest number of main runners/plant, number of leaves/transplant, the thickest transplant crown and the highest number of roots as well as the tallest roots/transplant were recorded by seaweed extract as a soil addition combined with seaweed extracts foliar spray treatment. In addition, the same treatment of seaweed extract either as a soil and foliar spray application induced the maximum number of produced transplants per plant and fedden during both seasons of study. Moreover, the combined treatment between soil addition of seaweed extract and folier spray exhibited the highest content of carbohydrates, phosphorus and potassium in tissues of produced transplants, whereas the highest total nitrogen content was recorded by soil addition of seaweed extract treatment combined with spraying transplants with amino acids in the two seasons. However, the tallest transplants were scored by combination treatment of seaweed extract added to the soil and $\mathrm{GA}_{3}$ folior spray. Furthermore, the lowest percentage of transplants infection was gained as a result of the combination treatment of EM soil addition and seaweed foliar spray.
\end{abstract}

Key words: Strawberry transplants cv. Festival, growth stimulants, soil addition, spraying, growth, chemical composition and quality.

\section{Introduction}

Strawberry (Fragaria $X$ ananassa Duch.) is one of the most important vegetable crops grown in Egypt for fresh consumption, processing and exportation. It's the unique vegetable crop belong to Rosaceae family. Due to the expansion of strawberry nursery cultivation transplants production has become an important industry in Egypt. Increasing the production with high quality transplants per feddan is very desirable by strawberry nurserymen. This may be achieved by using some growth stimulators, i.e., gibberellic acid, seaweed extract, amino acids, humic acid, compost tea and effective microorganisms (EM) either as soil addition or as foliar spray.

The plant growth regulator, gibberellin functions as one of the key signals regulating the developmental fate of vegetative buds in strawberry and runners production (Hytonen et al., 2009). In this connection, Ozdemir et al. (2009) showed that the application of $\mathrm{GA}_{3}$ significantly increased the growth and number of runners of strawberry plants as compared to thecontrol. Also, Ragab et al. (2010) showed that $\mathrm{GA}_{3}$ at $50 \mathrm{ppm}$ significantly increased number of transplants, crown diameter and total carbohydrates content in roots and crown of strawberry transplants.

Amino acids are extremely important biological compounds that play central roles both as building blocks of proteins and as intermediates in metabolism (Aberg, 1961), as well as stimulantion of pigment accumulation, resulting in greener leaves with greater photosynthetic efficiency which positively affect plant growth. In this regard, Abo Sedera et al. (2010) reported that spraying strawberry plants with amino acids at 0.5 and $1 \mathrm{~g} / 1$ increased vegetaative growth (plant height, number of crowns and number of leaves). Also, Shafshak $\boldsymbol{e t}$ al. (2011) found that amino acids increased vegetative growth and chemical constituents of strawberry plant foliage. Fruthermore, Shehata et al.(2011) reported that limited effects on growth of strawberry plants were observed by foliar fertilizer with either amino or humic acids .

Compost tea is a liquid extract produced by disolvig compost with water. It will contain soluble nutrients as both organic and inorganic and microorganisms including bacteria, fungi and protozoa. Anecdotal evidence suggests that these teas may be effective against pathogens. These organisms may work by inducing plant resistance, inhibiting pathogen growth, or outcompeting the pathogens. (Pane et al., 2012). The diverse microbial profile in compost tea help the plant leaves absorb nutrients from the air, and as they find their way into the soil, they help the plants root system to uptake nutreints from the soil (Scheuerell and Mahaffee, 2004). Jennifer et al. (2009) demonstrated that compost tea treatments provided simliar amounts of most macro- 
and micronutrients compared to compost and increased $\mathrm{N}, \mathrm{P}, \mathrm{K}, \mathrm{Ca}$ content of strawberry plant.

Humic acid (polymeric polyhydroxy acid) is the most significant component of organic substances in aquatic systems. Humic acid is highly beneficial to both plant and soil; through increasing microbial activity. It is considered as a plant growth biostimulant and an effective soil enhancer since it promotes nutrient uptake as chelating agent and improves vegetative characteristics of plant nutritional status and leaf pigments, it also activates the beneficial soil microorganisms and the availability of soil nutrients, particularly in alkaline soils and soils of low organic matter content. Also, humic materials may increase root growth in a similar manner to auxins (Berlyn and Russo, 1990). Khalid et al. (2013) reported that humic acid postively improved plant height, crown diameter, number of runners and number of leaves as well as enhaning root length of strawberry plants.

Bio-fertilization is considered an important tool to enhance the growth and quality of vegetable crops and it becomes, as positive alternative to chemical fertilizers. It is safe for human and environment and it is accompanied with reducing the great pollution occurred on our environment as well as for producing organic foods for export. Effective Microorganisms (EM) preparation contains milk bacteria (Lactobacillus casei, Streptococcus lactis), photosynthetic bacteria (Rhodopseudomonas palustrus and Rhodobacter space), yeast (Saccharomyces albus and Candida utilis), actinomycetes (Streptomyces albus and Streptomyces griseus) and moulds (Aspergillus oryzae and Mucom hiemalis) (Allahverdiyev et al., 2011)

Seaweed extract components are known as a source of plant growth regulators. Moreover, seaweed extracts have been found to contain significant amounts of cytokinins, auxins and betaines, which influence cell division during the early stages of growth along with the induction of flower formation (Jameson, 1993). Seaweed extract application could have promoted cell division, which increases the vegetative growth and fruit size in later stages. Also, it increases flower formation and thus

total fruit production, while by enhancing chlorophyll concentration could enhance $\mathrm{CO} 2$ assimilation rate. Moreover, seaweed has been shown to increase the source of plant assimilates by enhancing nutrient uptake, nitrate reduction and photosynthesis thus increasing assimilates supply to the plant (Blunden et al., 1997). Shafshak et al. (2011) reported that soil addition of seaweed extract increased strawberry vegetative growth. Rosalba et al. (2013) studied the effect of seaweed extract either as soil addition or foliar spray on tomato growth. Results indicated that using seaweed extract increased plant vegetative growth traits (plant height, fresh and dry weight of plant) and plant productivity. Also, Abo Sedera et al. (2014) reported that foliar spray of strawberry plants with two levels of seaweed extract 0.75 and $1.5 \mathrm{ml} / 1$ gave the highest significant values in all tested vegetative growth characters compared with other treatments.

Therefore, this study was an attempt to enhance the production and quality of strawberry transplants cv. Festival by using humic acid, seaweed extract, compost tea and effective microorganisms (EM) through soil addition and the foliar spray with amino acids, seaweed extract and gibberellic acid.

\section{Materials and Methods}

Two field experiments were carried out during two successive seasons of 2013 and 2014 in private Sector Farm at Kafr Elsohbi Village, Qalubia Governorate, to investigate the effect of soil addition of humic acid, seaweed extract, compost tea and effective microorganisms (EM) and the foliar spray with amino acids, seaweed extract and gibberellic acid as well as their combination on growth, chemical composition, production and quality of strawberry transplants (Fragaria $X$ ananassa Duch) cv. Festival. Nursery mother transplants of the used cultivar were obtained from Peico Company and planted on $23^{\text {th }}$ April and $1^{\text {st }}$ May in the first and second seasons, respectively. Mechanical and chemical analyses of the used soil are shown in Table a.

Table a: Mechanical and chemical analyses of the used soil.

\begin{tabular}{|c|c|c|c|c|c|}
\hline \multirow{2}{*}{\multicolumn{2}{|c|}{ Physical analysis }} & \multicolumn{4}{|c|}{ Chemical analysis } \\
\hline & & \multicolumn{2}{|c|}{ Cations (meq/l) } & \multicolumn{2}{|c|}{ Anions (meq/I) } \\
\hline Coarse sand & $19.5 \%$ & $\mathrm{Ca}^{++}$ & 8.90 & $\mathrm{CO}_{3}^{--}$ & Zero \\
\hline Fine sand & $35.6 \%$ & $\mathrm{Mg}^{++}$ & 3.15 & $\mathrm{HCO}_{3}^{-}$ & 4.60 \\
\hline Silt & $26.8 \%$ & $\mathrm{Na}^{+}$ & 4.20 & $\mathrm{Cl}^{-}$ & 5.35 \\
\hline Clay & $18.1 \%$ & $\mathrm{~K}^{+}$ & 1.18 & $\mathrm{SO}_{4}^{--}$ & 7.23 \\
\hline \multicolumn{6}{|c|}{ Texture class: Sandy loam } \\
\hline Soil $\mathrm{pH}$ & 7.2 & Available $\mathrm{N}$ & \multicolumn{2}{|c|}{$24.1 \mathrm{mg} / \mathrm{kg}$} & \\
\hline E.C $(\mathrm{dS} / \mathrm{m})$ & 1.73 & Available $\mathrm{P}$ & \multicolumn{2}{|c|}{$11.8 \mathrm{mg} / \mathrm{kg}$} & \\
\hline Organic matter & $2.1 \%$ & Available $\mathrm{K}$ & \multicolumn{2}{|c|}{$178 \mathrm{mg} / \mathrm{kg}$} & \\
\hline
\end{tabular}

Mixture of compost and chicken manure were added at rate of $40 \mathrm{~m}^{3}$ /feddan during soil preparation, three weeks before cultivation process. Soil fumigation by methyl bromide at $50 \mathrm{~g} / \mathrm{m}^{2}$ was used to 
sterilize the soil. Mother plants were dipped in $0.3 \%$ rhizolex solution for 20 minutes before transplanting. The transplants were spaced at $1.25 \mathrm{~m}$ between plants and $1.25 \mathrm{~m}$ between rows. Flowers were continuously removed from mother plants during the first month after transplanting. Drip irrigation system in the first two months was used, and then the micro sprinkler irrigation system $(4 \mathrm{~m} \quad \mathrm{x} \quad 5 \mathrm{~m})$ was used. All agricultural practices for cultivation, fertilization, irrigation, pest and diseases control were conducted as commonly followed according to the recommendation of the Ministry of Agriculture, Egypt for the commercial production of strawberry transplants in nursery.

The experimental design was split plot design with three replicates where the soil addition treatments were distributed in the main plots, while the spray treatments were located randomly in the sub plots. Each experimental plot contained one row with $1.25 \mathrm{~m}$ wide and $12.50 \mathrm{~m}$ long (plot area $=15.62 \mathrm{~m}^{2}$ ) which containing ten mother plants planted at distance $1.25 \mathrm{~m}$ in-between.

This experiment included 20 treatments resulted from the combination between five soil additions treatments and four spray treatments as follows.

\section{a. Soil addition treatments:}

1- Humic acid as Humic total at 5g/plant.

2- Seaweed extract as Rootmost at $5 \mathrm{ml} /$ plant.

3- Compost tea at $10 \mathrm{ml} /$ plant (its chemical composition are shown in Table, $b)$.

4- Effective microorganisms (EM) (contains photosynthetic bacteria +lactic acid +yeasts) at $5 \mathrm{ml} / \mathrm{plant}$, which purchased from
Department of Microbiology, Agric. Res. Center., Giza.

5- The control treatment (without any addition). b. Spray treatments.

1- Amino acids as Amino power at $2 \mathrm{ml} / \mathrm{l}$.

2- Seaweed extract at $2 \mathrm{ml} / 1$.

3- Gibberellic acid $\left(\mathrm{GA}_{3}\right)$ at $50 \mathrm{ppm}$.

4-The control treatment (spray with tap water).

Humic Total: $80 \%$ soluble potassium humate. It is commercial product by Leili Agrochemistry Co. Ltd. It includes: Humic acid $80 \%-\mathrm{K}_{2} \mathrm{O} \quad 11-13 \%$ Moisture 5-7\%.

Rootmost: Seaweed root growth promoter. It is commercial product by Leili Agrochemistry Co.Ltd. It includes: Seaweed extract 400g/l - Organic Matter $20 \mathrm{~g} / \mathrm{l}$.

Amino power: Is commercial product from Union for Agriculture Development (UAD) contain 20\% free L. amino acids , $40 \%$ total amino acids , 3\% mix of vitamins , $3.5 \%$ potassium citrate and some micro nutrients such as $1500 \mathrm{ppm} \mathrm{Fe}$ 500ppm $\mathrm{Zn}$ and 500ppm Mn.

Compost tea preparation: compost tea was prepared by soaking $10 \mathrm{~kg}$ of mature plant compost with 100 liter of water $+100 \mathrm{ml}$ molasses for 7days in special unit, attached to air pump and the aerator provides continuous flow of air bubbles to extract compost tea until completion of the fermentation process and extract color becomes light Brown (Fayek et al., 2014)

Table b: Chemical and microbiological analyses of compost tea.

\begin{tabular}{lllllllll}
\hline parameter & PH & $\begin{array}{l}\text { EC } \\
(\mathrm{dS} / \mathrm{m})\end{array}$ & $\begin{array}{l}\text { Total } \\
\mathrm{N} \%\end{array}$ & $\begin{array}{l}\text { Total } \\
\mathrm{p} \%\end{array}$ & $\begin{array}{l}\text { Total } \\
\mathrm{k} \%\end{array}$ & $\begin{array}{l}\text { Total count of } \\
\text { bacteria }(\mathrm{cfu} / \mathrm{ml})\end{array}$ & $\begin{array}{l}\text { Total count of } \\
\text { fungi }(\mathrm{cfu} / \mathrm{ml})\end{array}$ & $\begin{array}{l}\text { Total count of } \\
\text { actinomycetes }(\mathrm{cfu} / \mathrm{ml})\end{array}$ \\
\hline value & 7.14 & 2.83 & 0.34 & 0.08 & 0.56 & $8.7 \times 10^{6}$ & $7.7 \times 10^{4}$ & $1.1 \times 10^{5}$ \\
\hline
\end{tabular}

The soil addition treatments were added through drip irrigation water (fertigation) three times starting 15 days after transplanting and every two weeks by interval.

The spray treatments were started one month from transplanting and repeated at 15 days intervals conducted six times through the growing season. The spray solution was maintained just to cover completely the plant foliage. As for the agricultural practices, runners were manual fixed twice a week during the growing season, starting from the first runnering (after 30days from transplanting) till late August, then stopped until the end of the growing season. In addition, mother plants were defoliated by removing the old, dry and dead leaves three times monthly during June, July and August, then stopped until the end of season.

\section{Data recorded}

Representative samples of three mother plants with their runners and daughter plants were dug on $20^{\text {th }}$ September to record the vegetative growth characteristics, i.e., number of main runners/plant, number of leaves/transplant, plant height, crown diameter, number of fresh transplants per plant and per feddan, number of roots and root length of transplant. Total carbohydrates, nitrogen, phosphorus and potassium were determined according to A. $\mathbf{O}$. A. C. (1990), Pregl (1945), John (1970) and Brown and Lilleland (1946), respectively. As for disease assessment, infection percentage was estimated in 20th September in transplants according to the method of Dhingra and Sinclair (1995).

\section{Statistical analysis:}

All data obtained in both seasons of study were subjected to analysis of variance as factorial experiments in split plot design. Duncan's analysis 
was used to differentiate means according to Snedecor and Cochran (1991).

\section{Results and Discussion}

\section{1- Number of main runners and leaves/plant}

Data in Table1 reveal that the number of main runners and leaves/plant was significantly increased by using all tested soil additions of growth stimulants compared with the control treatment. In this respect, seaweed extract at $5 \mathrm{ml} /$ plant exhibited the highest values for both number of main runners and leaves/plant, followed by $5 \mathrm{~g} /$ plant humic acidtreated plant as compared with the control in the two seasons. In addition, all tested growth stimulants sprays succeeded in increasing the number of main runners and leaves /plant, especially the treatment of seaweed at $2 \mathrm{ml} / 1$, followed in descending order by amino acids at $2 \mathrm{ml} / \mathrm{l}$ in the two seasons.

As for the interaction effect between soil addition and spray treatments of the tested growth stimulants, data in the same Table, clearly show that all resulted interactions statistically increased the number of main runners and leaves/plant when compared with un-treated plants "control" in the two seasons. Furthermore, the highest number of main runners and leaves /plant was recorded by the combination between seaweed extract at $5 \mathrm{ml} /$ plant as a soil addition and spraying seaweed extract at $2 \mathrm{ml} / 1$ as it scored 12.95, 7.46 and 11.48, 6.80 main runners and leaves/plant during first and second seasons, respectively, followed in descending order by the combined treatment of humic acid at $5 \mathrm{~g}$ /plant and spraying seaweed at $2 \mathrm{ml} / \mathrm{l}$ as it recorded $12.26,10.97$ main runners in case of number of main runners and the combined treatments between seaweed extract and amino acids which scored 7.15 and 6.32 leaves/plant in the first and second seasons, respectively. Such increment in the studied vegetative growth traits may be due to the biological and physiological roles of the used growth stimulants where seaweed extract which contain large amount of cytokinins and auxin which induce cell division thus increase the vegetative growth. In addition, humic acid enhanced vegetative growth as it promotes nutrient uptake, nutritional status and leaf pigments. Moreover, EM produces adequate amounts of phytohormones such as IAA, $\mathrm{GA}_{3}$ and cytokinins which affect the vegetative growth of strawberry transplants. Furthermore, compost tea containing soluble nutrients which were necessary for vegetative growth. Also, amino acids play an important role in protein synthesis as well as stimulation of pigment accumulation resulting in greener leaves with greater photosynthetic efficiency which positively affect vegetative growth. It may be also due to the role of $\mathrm{GA}_{3}$ which caused an increase in the main runners number, length of cells and the elangation of internodes. The obtained results are in agreement with those reported by Ragab (1996), Hytonen et al.(2009), Jennifer et al.(2009), Ozdemir et al. (2009), Abo Sedera et al.(2010), Ragab et al. (2010), Shafshak et al.(2011), Shehata et al.(2011), Khalid et al.(2013), and Abo Sedera et al.(2014) on strawberry. Pane et al.(2012) and Rosalba et al.(2013) on tomato.

\section{2-plant height and crown diameter.}

Data tabulated in Table 2 indicate that there were significant differences among the tested soil addition treatments in both plant height and crown diameter of produced strawberry transplants during both seasons of growth. In this respect, treating transplants with seaweed extract at $5 \mathrm{ml} /$ plant three times during the growth seasons reflected the highest values, followed by using the humic acid at $5 \mathrm{~g} /$ plant, EM at $5 \mathrm{ml} /$ plant, compost tea at $10 \mathrm{ml} / \mathrm{plant}$ and the control treatment in a descending order. Such increments in plant height and crown diameter may be due to the main role of chemical constituents of seaweed extract, humic acid, EM and compost tea on cell division and cell elongation which positively affect on transplants length and diameter of crown. Also, the enhancement effect may be due to the increasing of $\mathrm{N}, \mathrm{P}, \mathrm{K}$ absorption and carbohydrates assimilation (Tables 4 and 5) and in turn affected positively transplants growth.

Concerning the effect of foliar spray treatments, the same data in Table 2 show clearly that spraying strawberry transplants with all tested growth stimulants six times starting one month from transplanting and every two weeks by intervals significantly affected both transplants height and crown diameter compared to the control treatment. In this connection, using gibberellic acid at $50 \mathrm{ppm}$ exhibited the highest values in this respect as compared with other tested treatments. In addition, seaweed extract ranks the second followed by using amino acids. Such results are true during both seasons of study in case of plant height. Furthermore, spraying strawberry transplants with seaweed extract gave the highest value of crown diameter.

As for the interaction treatments, data in Table 2 indicate that the highest values of transplants height and crown diameter were recorded as a result of using seaweed extract as a soil addition supported with spraying transplants with gibberellic acid in case of transplants height and seaweed as soil application combined with seaweed as a foliar spray in case of crown diameter in the two seasons. 
Table 1. Effect of some plant biostimulants as soil addition and foliar spray and their interactions on number of main runners/plant and number of leaves /plant during 2013 and 2014 seasons

\begin{tabular}{|c|c|c|c|c|c|c|c|c|c|c|}
\hline \multirow[t]{2}{*}{ Treatments } & \multicolumn{4}{|c|}{ Number of main runners/plant } & \multicolumn{4}{|c|}{ Number of leaves /plant } & \multirow[b]{3}{*}{ Control } & \multirow[b]{3}{*}{ Mean } \\
\hline & \multicolumn{8}{|c|}{ First season ( 2013) } & & \\
\hline $\begin{array}{r}\text { Spray (B) } \\
\text { Soil addition (A) }\end{array}$ & $\begin{array}{c}\text { Amino } \\
\text { acid }\end{array}$ & $\begin{array}{c}\text { Seaweed } \\
\text { extract }\end{array}$ & $\begin{array}{c}\text { Gibberellic } \\
\text { acid }\end{array}$ & Control & Mean & $\begin{array}{c}\text { Amino } \\
\text { acid }\end{array}$ & $\begin{array}{c}\text { Seaweed } \\
\text { extract }\end{array}$ & $\begin{array}{c}\text { Gibberellic } \\
\text { acid }\end{array}$ & & \\
\hline Humic acid & $10.27 \mathrm{hi}$ & $12.26 \mathrm{~b}$ & $10.98 \mathrm{ef}$ & $9.83 \mathrm{k}$ & $10.84 B$ & $6.93 \mathrm{~cd}$ & $7.10 \mathrm{~b}$ & $6.72 \mathrm{ef}$ & $6.25 \mathrm{gh}$ & 6.74B \\
\hline Seaweed extract & $11.34 \mathrm{~d}$ & $12.95 \mathrm{a}$ & $11.72 \mathrm{c}$ & $10.13 \mathrm{ij}$ & $11.53 \mathrm{~A}$ & $7.15 b$ & $7.46 \mathrm{a}$ & $7.08 \mathrm{bc}$ & $6.83 \mathrm{de}$ & $7.13 \mathrm{~A}$ \\
\hline Compost tea & $10.16 \mathrm{ij}$ & $11.20 \mathrm{de}$ & $10.25 \mathrm{hi}$ & $9.71 \mathrm{k}$ & $10.33 \mathrm{C}$ & $6.36 \mathrm{~g}$ & $6.84 \mathrm{de}$ & $6.27 \mathrm{gh}$ & $5.41 \mathrm{~L}$ & $6.22 \mathrm{D}$ \\
\hline Effective microorganism(EM) & $10.52 \mathrm{gk}$ & $11.84 \mathrm{c}$ & $10.83 f$ & $9.95 \mathrm{jk}$ & 10.78B & $6.78 \mathrm{~d}: \mathrm{h}$ & $6.90 \mathrm{~d}$ & $6.66 f$ & $5.81 \mathrm{j}$ & $6.55 \mathrm{C}$ \\
\hline Control & $9.80 \mathrm{k}$ & $10.79 \mathrm{fg}$ & $9.82 \mathrm{k}$ & 8.561 & 9.74D & $6.02 \mathrm{ij}$ & $6.17 \mathrm{hi}$ & $5.60 \mathrm{k}$ & $5.10 \mathrm{~m}$ & $5.72 E$ \\
\hline \multirow[t]{2}{*}{ Mean } & $10.42 \mathrm{C}$ & $11.81 \mathrm{~A}$ & 10.72B & 9.63D & & 6.64B & 6.89A & 6.46C & 5.89D & \\
\hline & \multicolumn{10}{|c|}{ Second season (2014) } \\
\hline Humic acid & $10.22 \mathrm{~d}$ & $10.97 \mathrm{~b}$ & $10.15 \mathrm{de}$ & $9.20 \mathrm{~h}$ & 10.14B & $5.92 \mathrm{a}: \mathrm{c}$ & $6.31 \mathrm{ab}$ & $5.75 b c$ & $5.10 \mathrm{c}-\mathrm{e}$ & 5.77B \\
\hline Seaweed extract & $10.81 b c$ & $11.48 \mathrm{a}$ & $10.93 b$ & 10.10de & $10.83 A$ & $6.32 \mathrm{ab}$ & $6.80 \mathrm{a}$ & $6.18 \mathrm{ab}$ & $5.43 \mathrm{~b}-\mathrm{d}$ & 6.18A \\
\hline Compost tea & $9.56 \mathrm{f}$ & $9.91 \mathrm{e}$ & $9.27 \mathrm{gh}$ & $8.63 \mathrm{k}$ & 9.34D & $5.16 \mathrm{~cd}$ & $5.51 \mathrm{~b}-\mathrm{d}$ & $4.93 \mathrm{c}-\mathrm{e}$ & $4.53 \mathrm{de}$ & $5.03 B$ \\
\hline Effective microorganism(EM) & $9.57 \mathrm{f}$ & $10.62 \mathrm{c}$ & $9.45 f g$ & $9.12 \mathrm{hi}$ & $9.69 \mathrm{C}$ & $5.13 \mathrm{~cd}$ & $5.87 \mathrm{a}-\mathrm{c}$ & $5.10 \mathrm{c}-\mathrm{e}$ & $4.73 \mathrm{de}$ & $5.20 \mathrm{~B}$ \\
\hline Control & $8.90 \mathrm{ij}$ & $9.36 \mathrm{f}-\mathrm{h}$ & $8.79 \mathrm{jk}$ & 7.431 & $8.62 \mathrm{E}$ & $4.93 \mathrm{c}-\mathrm{e}$ & $5.18 \mathrm{~cd}$ & 4.74de & $4.12 \mathrm{e}$ & 4.74B \\
\hline Mean & 9.81B & $10.47 \mathrm{~A}$ & 9.71B & $8.89 c$ & & 5.49AB & $5.93 A$ & 5.34B & $4.78 C$ & \\
\hline
\end{tabular}

Means of the same column followed by the same letter were not significantly different according to Duncan MRT at5\% 
Table 2. Effect of some plant biostimulants as soil addition and foliar spray and their interactions on plant height and crown diameter during 2013 and 2014 seasons.

\begin{tabular}{|c|c|c|c|c|c|c|c|c|c|c|}
\hline \multirow{2}{*}{ Treatments } & \multicolumn{5}{|c|}{ Plant height $(\mathrm{cm})$} & \multicolumn{5}{|c|}{ Crown diameter $(\mathrm{cm})$} \\
\hline & \multicolumn{10}{|c|}{ First season ( 2013) } \\
\hline $\begin{array}{r}\text { Spray (B) } \\
\text { Soil addition (A) }\end{array}$ & $\begin{array}{l}\text { Amino } \\
\text { acid }\end{array}$ & $\begin{array}{c}\text { Seaweed } \\
\text { extract }\end{array}$ & $\begin{array}{c}\text { Gibberellic } \\
\text { acid }\end{array}$ & Control & Mean & $\begin{array}{c}\text { Amino } \\
\text { acid }\end{array}$ & $\begin{array}{c}\text { Seaweed } \\
\text { extract }\end{array}$ & $\begin{array}{c}\text { Gibberellic } \\
\text { acid }\end{array}$ & Control & Mean \\
\hline Humic acid & $25.13 \mathrm{a}-\mathrm{d}$ & $25.56 \mathrm{a}-\mathrm{c}$ & $25.80 \mathrm{ab}$ & $23.80 \mathrm{~d}-\mathrm{g}$ & 25.07AB & $0.97 \mathrm{c}-\mathrm{f}$ & $1.06 \mathrm{~b}$ & $0.91 \mathrm{~g}-\mathrm{i}$ & $0.87 \mathrm{~h}-\mathrm{k}$ & $0.95 B$ \\
\hline Seaweed extract & $25.65 a-c$ & $25.90 \mathrm{a}$ & $26.13 \mathrm{a}$ & $24.25 \mathrm{c}-\mathrm{g}$ & $25.48 \mathrm{~A}$ & $1.01 \mathrm{~g}-\mathrm{i}$ & $1.13 \mathrm{c}-\mathrm{f}$ & $0.98 \mathrm{~b}$ & $0.91 \mathrm{~g}-\mathrm{i}$ & 1.01A \\
\hline Compost tea & $24.76 a-f$ & $24.95 a-e$ & $25.17 \mathrm{a}-\mathrm{d}$ & $23.12 \mathrm{~g}$ & 24.50B & $0.92 \mathrm{f}-\mathrm{h}$ & $0.95 \mathrm{e}-\mathrm{g}$ & $0.86 \mathrm{i}-\mathrm{k}$ & 0.801 & $0.88 D$ \\
\hline Effective microorganism(EM) & $24.98 \mathrm{a}-\mathrm{e}$ & $25.15 a-d$ & $25.62 \mathrm{a}-\mathrm{c}$ & $23.25 \mathrm{fg}$ & 24.75AB & $0.96 \mathrm{~d}-\mathrm{g}$ & $1.02 \mathrm{bc}$ & $0.88 \mathrm{~h}-\mathrm{j}$ & $0.84 \mathrm{j}-1$ & $0.92 \mathrm{C}$ \\
\hline Control & $23.50 \mathrm{e}-\mathrm{g}$ & $23.84 \mathrm{~d}-\mathrm{g}$ & $24.36 \mathrm{~b}-\mathrm{g}$ & $22.93 \mathrm{~g}$ & $23.66 \mathrm{C}$ & $0.84 \mathrm{j}-1$ & $0.91 \mathrm{~g}-\mathrm{i}$ & $0.82 \mathrm{kl}$ & 0.791 & $0.84 \mathrm{E}$ \\
\hline \multirow[t]{2}{*}{ Mean } & $24.80 \mathrm{~A}$ & $25.08 A$ & $25.42 \mathrm{~A}$ & 23.47B & & $0.94 B$ & $1.01 \mathrm{~A}$ & $0.89 \mathrm{C}$ & 0.84D & \\
\hline & \multicolumn{10}{|c|}{ Second season (2014) } \\
\hline Humic acid & $23.15 \mathrm{~d}-\mathrm{f}$ & $23.87 \mathrm{~b}-\mathrm{d}$ & $24.36 \mathrm{ab}$ & $22.10 \mathrm{~g}-\mathrm{i}$ & 23.37B & $0.95 \mathrm{a}-\mathrm{c}$ & $0.97 \mathrm{ab}$ & $0.90 \mathrm{~b}-\mathrm{e}$ & $0.84 c-f$ & 0.91AB \\
\hline Seaweed extract & $23.92 b c$ & $24.13 \mathrm{ab}$ & $24.78 \mathrm{a}$ & $22.64 \mathrm{e}-\mathrm{h}$ & 23.87A & $0.99 \mathrm{ab}$ & $1.04 \mathrm{a}$ & $0.93 \mathrm{a}-\mathrm{d}$ & $0.90 \mathrm{~b}-\mathrm{e}$ & $0.96 A$ \\
\hline Compost tea & $22.72 \mathrm{e}-\mathrm{g}$ & $23.01 \mathrm{ef}$ & $23.93 b c$ & $21.32 \mathrm{k}$ & $22.74 C$ & $0.89 \mathrm{~b}-\mathrm{e}$ & $0.92 \mathrm{a}-\mathrm{d}$ & $0.84 c-f$ & $0.81 \mathrm{~d}-\mathrm{f}$ & $0.86 \mathrm{BC}$ \\
\hline Effective microorganism(EM) & $22.95 \mathrm{ef}$ & $23.25 \mathrm{c}-\mathrm{e}$ & 24. $11 \mathrm{ab}$ & $21.92 \mathrm{~h}-\mathrm{k}$ & 23.06BC & $0.93 a-d$ & $0.96 \mathrm{a}-\mathrm{c}$ & $0.89 \mathrm{~b}-\mathrm{e}$ & $0.81 \mathrm{~d}-\mathrm{f}$ & $0.89 A$ \\
\hline Control & $21.35 \mathrm{jk}$ & $21.84 \mathrm{i}-\mathrm{k}$ & $22.46 \mathrm{f}-\mathrm{i}$ & $20.16 \mathrm{~L}$ & 21.45D & $0.81 \mathrm{~d}-\mathrm{f}$ & $0.87 \mathrm{~b}-\mathrm{f}$ & $0.78 \mathrm{ef}$ & $0.76 f$ & $0.80 \mathrm{C}$ \\
\hline Mean & 22.82C & 23.22B & 23.93A & 21.63D & & 0.91AB & $0.95 A$ & 0.86BC & $0.82 \mathrm{C}$ & \\
\hline
\end{tabular}

Means of the same column followed by the same letter were not significantly different according to Duncan MRT at5\% 
Obtained results are in agreement with those reported by Ragab (1996), Hytonen et al.(2009), Jennifer et al.(2009), Ozdemir et al. (2009), Abo Sedera et al.(2010), Ragab et al. (2010), Shafshak et al.(2011), Shehata et al.(2011), Khalid et al.(2013), and Abo Sedera et al.(2014) on strawberry and Pane et al.(2012) and Rosalba et al.(2013) on tomato .

\section{3-Number and length of the transplant roots:}

Data in Table 3 illustrate the effect of soil addition and foliar spray with tested growth stimulant treatments as well as their interaction on number and length of roots per transplants. Such data indicate that soil treatments with humic acid at $5 \mathrm{~g} / \mathrm{plant}$, seaweed extract at $5 \mathrm{ml} / \mathrm{plant}$, compost tea at $10 \mathrm{ml} /$ plant and EM at $5 \mathrm{ml} /$ plant three times during the growth season starting 15 days after transplanting and every two weeks by interval significantly increased both number and length of roots produced by treated transplants compared with the control treatment. In this connection, seaweed extract recorded the highest number of roots and longest roots /plant, followed in descendingly by humic acid, EM and compost tea during the two seasons of growth. In this respect, such positive effect of tested growth stimulants may be due to its physiological and biological constituents which enhanced roots formation and elongation and consequently increased its growth.

With regard to the effect of spray treatments, the same data in Table 3 show that spraying transplants six times during the growing season starting after one month from transplanting and two weeks by intervals with amino acids at $2 \mathrm{ml} / \mathrm{l}$, seaweed extract at $2 \mathrm{ml} / 1$ and gibberellic acid at 50 ppm significantly increased number and length of roots per transplant compared to the check treatment (control) in both seasons of study. In addition, using seaweed extract reflected the highest values in this respect. Moreover, no significant differences were noticed between treatments of amino acid and gibberellic acid in this regard.

As for the interaction the same data in Table 3 indicate that the highest number of roots $(26.42$ and 25.75 roots/transplant) as well as the tallest roots/transplant $(14.64$ and $13.73 \mathrm{~cm})$ were recorded by the combined treatment of soil addition of seaweed and spraying seaweed extract, followed by soil addition of humic acid provided with seaweed extract foliar spray in the two seasons. Furthermore, soil addition of seaweed extract enriched with amino acids registered high increments in these parameters . The enhancement in roots number and length may be due to the role of used growth stimulants, i.e., GA3, amino acids, humic acid, seaweed extract and EM in encouragement cell division and cell elongation as well as increasing nutrient uptake (Tables 4 and 5)and photosynthetic assimilation rate which in turn affect positively roots number and length . Obtained results go in line with those reported by Ragab (1996), Ragab et al. (2010) and Khalid et al. (2013) on strawberry.

\section{4- Chemical composition determination}

Data in Tables 4 and 5 show clearly that all tested soil additions of growth stimulants increased total carbohydrates, nitrogen, phosphprus and potassium contents of strawberry cv. Festival transplants compared with the control treatment. In this respect, seaweed extract treatment show the superiority, followed in a descending order by humic acid and EM treatments in the two seasons. With regard to the effect of foliar spray treatments, the same data in Tables 4 and 5 show that chemical composition determination of strawberry transplants statistically increased by using all studied spray treatments of growth stimulants, particularly seaweed extract, followed by amino acid with the exception of nitrogen $\%$ as amino acids foliar spray treatment show its superiority in this respect as compared with the control plants in the two seasons. However, the combined treatments between soil addition of seaweed extract and spraying seaweed extract showed to be the most effective one for producing the highest total carbohydrates (8.30 and $7.72 \%)$, phosphorus $(0.46$ and $0.39 \%)$ and potassium (1.93 and $1.85 \%)$, whereas the highest nitrogen content (2.89 and $2.79 \%$ ) was registered by soil addition of seaweed extract treatment combined with spraying amino acids treatment in the first and second seasons, respectively.

The increases in the studied chemical composition may be due to the physiological effects of growth stimulants, amino acids stimulated pigment accumulation, resulting in greener leaves with greater photosynthetic efficiency which was reflected on more chemical composition in strawberry plants. In addition, compost tea help the plants root system to absorb nutrients from the soil which induced more chemical composition in strawberry plants. Also, humic acid promotes nutrient uptake and improve leaf pigments and chemical composition of strawberry plants. Moreover, EM stimulates the meristematic activities of cells and tissues, thereby promoting vegetative growth aspects which were reflected in chemical constituents (Allahverdiyer $\boldsymbol{e t}$ al., 2011). Obtained results are similar to those reported by Ragab (1996), Hytonen et al. (2009), Jennifer et al.(2009), Ozdemir et al. (2009), Abo Sedera et al.(2010), Ragab et al. (2010), Shafshak et al.(2011), Shehata et al.(2011), Khalid et al.(2013) and Abo Sedera et al.(2014) on strawberry .

5- Number of transplants/ plant and per feddan.

Data in Table 6 illustrate that all tested soil additions of growth stimulants significantly increased the number of transplants/plant and per fed. In this connection, seaweed extract treatment reflected the highest number of produced transplants 
followed in a descending order by humic acid and E.M treatments as compared with the control in the two seasons. Additionally, all tested spray treatments of the used growth stimulants resulted in highly significant increments in these aforementioned parameters. Moreover, spraying seaweed extract exhibited the highest values followed in a descending order by amino acid and $\mathrm{GA}_{3}$ treatments when compared with the control plants in the two seasons.

Referring to the interaction effect between soil addition and spray treatments of the used growth stimulants, data in Table 6 demonstrated also that all resulted combinations succeeded in increasing the number of transplants/plant and per fed., with significant increase in most cases when compared with un-treated plants in the two seasons. Moreover, the highest number of transplants /plant and per feddan was scored by the combined treatment between soil addition of seaweed and spraying seaweed as it scored 94.35 and 89.83 transplants /plant and 254018 and 241849 transplants / fed. In the first and second seasons, respectively. Furthermore, soil addition of seaweed extract supplemented with amino acid or GA3 sprays recorded high significant increments in these parameters in the two seasons. Obtained results are similar to those reported by Ragab (1996), Hytonen et al.(2009), Jennifer et al.(2009), Ozdemir et al. (2009), Abo Sedera et al.(2010), Ragab et al. (2010), Shafshak et al.(2011), Shehata et al.(2011),
Khalid et al.(2013) and Abo Sedera et al.(2014) on strawberry and Pane et al.(2012) and Rosalba et al.(2013) on tomato.

\section{6- Infection \%:}

It is quite clear from Table 7 that infection percentage of strawberry transplants cv. Festival was significantly decreased by using all growth stimulants treatments which applied either by soil addition or by foliar spraying, as well as their combinations, when compared with un-treated plants in the two seasons. However, the lowest infection percentage was gained by the combined treatment between soil addition of E.M and spraying seaweed extract as it recorded 2.60 and $2.20 \%$ in the first and second seasons, respectively. Obtained results are in agreement with those reported by Ragab (1996), Hytonen et al.(2009), Jennifer et al.(2009), Ozdemir et al. (2009), Abo Sedera et al.(2010) and Ragab et al. (2010) on strawberry.

Conclusively, it could be concluded that under such condition, it is preferable to use growth stimulants, i.e., humic acid, seaweed extract, compost tea and effective microorganisms (EM) through soil addition and the foliar spray with amino acids, seaweed extract and gibberellic acid were recommended for enhancing the production and improving the quality of strawberry transplants. 
Table 3. Effect of some plant biostimulants as soil addition and foliar spray and their interactions on number of roots/transplant and root length during 2013 and 2014 seasons.

\begin{tabular}{|c|c|c|c|c|c|c|c|c|c|c|}
\hline \multirow{3}{*}{$\begin{array}{l}\text { Treatments } \\
\text { Spray (B) }\end{array}$} & \multicolumn{5}{|c|}{ Number of roots } & \multicolumn{5}{|c|}{ Root length(cm) } \\
\hline & \multicolumn{10}{|c|}{ First season ( 2013) } \\
\hline & $\begin{array}{l}\text { Amino } \\
\text { acid }\end{array}$ & $\begin{array}{c}\text { Seaweed } \\
\text { extract }\end{array}$ & $\begin{array}{c}\text { Gibberellic } \\
\text { acid }\end{array}$ & Control & Mean & $\begin{array}{c}\text { Amino } \\
\text { acid }\end{array}$ & $\begin{array}{c}\text { Seaweed } \\
\text { extract }\end{array}$ & $\begin{array}{c}\text { Gibberellic } \\
\text { acid }\end{array}$ & Control & Mean \\
\hline Humic acid & $25.43 b c$ & $25.96 \mathrm{ab}$ & $24.86 \mathrm{c}-\mathrm{e}$ & $23.65 \mathrm{f}-\mathrm{i}$ & 24.95B & $13.98 b-d$ & $14.19 \mathrm{ab}$ & $13.91 \mathrm{~b}-\mathrm{d}$ & $13.25 \mathrm{e}-\mathrm{g}$ & 13.83B \\
\hline Seaweed extract & $25.80 \mathrm{a}-\mathrm{c}$ & $26.42 \mathrm{a}$ & $25.64 a-c$ & $24.22 \mathrm{~d}-\mathrm{f}$ & 25.52A & $14.18 \mathrm{ab}$ & $14.64 \mathrm{a}$ & $14.07 \mathrm{a}-\mathrm{c}$ & $13.92 b-d$ & $14.20 \mathrm{~A}$ \\
\hline Compost tea & $24.05 \mathrm{e}-\mathrm{g}$ & $24.97 b-e$ & 23.91e-h & $22.63 \mathrm{i}$ & 23.89C & $13.26 \mathrm{e}-\mathrm{g}$ & $13.54 c-f$ & $13.09 \mathrm{fg}$ & $12.21 \mathrm{ij}$ & 13.03D \\
\hline Effective microorganism(EM) & $24.76 c-f$ & $25.18 b-d$ & $24.13 \mathrm{~d}-\mathrm{g}$ & $23.11 \mathrm{~g}-\mathrm{i}$ & 24.30C & $13.62 b-f$ & $13.87 \mathrm{~b}-\mathrm{e}$ & $13.40 \mathrm{~d}-\mathrm{g}$ & $12.88 \mathrm{gh}$ & $13.44 \mathrm{C}$ \\
\hline Control & 22.90hi & $23.25 \mathrm{f}-\mathrm{i}$ & $22.83 \mathrm{i}$ & $21.54 \mathrm{j}$ & 22.63D & $11.93 \mathrm{ij}$ & 12.40hi & $12.64 \mathrm{j}$ & $11.72 \mathrm{j}$ & 11.92E \\
\hline \multirow{2}{*}{ Mean } & 24.57B & $25.16 A$ & 24.27B & 23.03C & & 13.39B & 13.73A & 13.62B & $12.80 \mathrm{C}$ & \\
\hline & \multicolumn{10}{|c|}{ Second Season (2014) } \\
\hline Humic acid & $23.37 \mathrm{de}$ & $24.66 b$ & $23.05 \mathrm{e}-\mathrm{g}$ & $22.48 \mathrm{~g}-\mathrm{i}$ & 23.39B & $12.85 \mathrm{~d}$ & $13.33 b$ & $12.25 \mathrm{fg}$ & $12.04 \mathrm{hi}$ & $12.62 B$ \\
\hline Seaweed extract & $24.20 \mathrm{bc}$ & $25.75 \mathrm{a}$ & $24.10 \mathrm{bc}$ & $23.18 \mathrm{~d}-\mathrm{f}$ & 24.31A & $13.12 \mathrm{c}$ & $13.73 \mathrm{a}$ & $12.95 \mathrm{~cd}$ & $12.40 \mathrm{ef}$ & 13.05A \\
\hline Compost tea & $22.65 f-h$ & $23.72 \mathrm{~cd}$ & $22.44 \mathrm{~g}-\mathrm{i}$ & $21.60 \mathrm{i}$ & $22.60 \mathrm{C}$ & $12.17 \mathrm{gh}$ & $12.86 \mathrm{~d}$ & 12.04hi & $11.55 \mathrm{k}$ & 12.15D \\
\hline Effective microorganism(EM) & $23.14 d-f$ & $24.22 \mathrm{bc}$ & $22.93 \mathrm{e}-\mathrm{g}$ & $22.17 \mathrm{~h}-\mathrm{j}$ & 23.11B & $12.52 \mathrm{e}$ & $13.07 \mathrm{c}$ & $12.12 \mathrm{~g}-\mathrm{i}$ & $11.96 \mathrm{ij}$ & $12.42 \mathrm{C}$ \\
\hline Control & $20.66 \mathrm{k}$ & $21.91 \mathrm{ij}$ & $20.14 \mathrm{k}$ & 19.351 & 20.51D & 11.161 & $11.80 \mathrm{j}$ & 11.051 & 10.841 & $11.30 \mathrm{E}$ \\
\hline Mean & 22.80B & 24.05A & 22.53B & $21.76 \mathrm{C}$ & & 12.36B & 12.96A & 12.08C & 11.83D & \\
\hline
\end{tabular}

Means of the same column followed by the same letter were not significantly different according to Duncan MRT at5\% 
Table 4. Effect of some plant biostimulants as soil addition and foliar spray and their interactions on total carbohydrates and nitrogen $\%$ during 2013 and 2014 seasons.

\begin{tabular}{|c|c|c|c|c|c|c|c|c|c|c|}
\hline \multirow{2}{*}{ Treatments } & \multicolumn{5}{|c|}{ Total carbohydrates \% } & \multicolumn{5}{|c|}{ Nitrogen $\%$} \\
\hline & \multicolumn{10}{|c|}{ First season ( 2013) } \\
\hline $\begin{array}{r}\text { Spray (B) } \\
\text { Soil addition (A) }\end{array}$ & Amino acid & $\begin{array}{l}\text { Seaweed } \\
\text { extract }\end{array}$ & $\begin{array}{c}\text { Gibberellic } \\
\text { acid }\end{array}$ & Control & Mean & $\begin{array}{l}\text { Amino } \\
\text { acid }\end{array}$ & $\begin{array}{l}\text { Seaweed } \\
\text { extract }\end{array}$ & $\begin{array}{c}\text { Gibberellic } \\
\text { acid }\end{array}$ & Control & Mean \\
\hline Humic acid & $7.90 \mathrm{~d}-\mathrm{f}$ & $8.06 b-d$ & $7.84 \mathrm{e}-\mathrm{f}$ & $7.28 \mathrm{~h}$ & 7.76B & $2.76 \mathrm{c}$ & $2.72 \mathrm{~cd}$ & $2.64 \mathrm{e}-\mathrm{g}$ & $2.95 \mathrm{~g}-\mathrm{j}$ & $2.67 B$ \\
\hline Seaweed extract & $8.16 \mathrm{a}-\mathrm{c}$ & $8.30 \mathrm{a}$ & $8.20 \mathrm{ab}$ & $7.96 c-e$ & 8.14A & $2.89 \mathrm{a}$ & $2.83 b$ & $2.74 \mathrm{c}$ & $2.68 \mathrm{de}$ & $2.78 \mathrm{~A}$ \\
\hline Compost tea & $7.28 \mathrm{~h}$ & $7.52 \mathrm{~g}$ & $6.96 \mathrm{i}$ & $6.62 \mathrm{j}$ & 7.08D & $2.63 \mathrm{e}-\mathrm{h}$ & $2.60 \mathrm{~g}-\mathrm{i}$ & $2.54 \mathrm{j}-1$ & $2.50 \mathrm{k}-\mathrm{m}$ & $2.56 \mathrm{D}$ \\
\hline Effective microorganism(EM) & $7.74 \mathrm{f}$ & $7.98 \mathrm{c}-\mathrm{e}$ & $7.72 \mathrm{fg}$ & $7.04 \mathrm{i}$ & 7.62C & $2.66 \mathrm{ef}$ & $2.61 \mathrm{f}-\mathrm{h}$ & $2.58 \mathrm{~h}-\mathrm{j}$ & $2.55 \mathrm{i}-\mathrm{k}$ & $2.60 \mathrm{C}$ \\
\hline Control & $6.24 \mathrm{k}$ & $6.86 \mathrm{i}$ & $6.08 \mathrm{k}$ & 5.721 & $6.22 \mathrm{E}$ & $2.51 \mathrm{kl}$ & $2.491 \mathrm{~m}$ & $2.45 \mathrm{mn}$ & $2.41 \mathrm{n}$ & $2.46 \mathrm{E}$ \\
\hline \multirow[t]{2}{*}{ Mean } & 7.46B & 7.74A & $7.36 \mathrm{C}$ & $7.28 \mathrm{D}$ & & $2.69 \mathrm{~A}$ & $2.65 B$ & $2.59 \mathrm{C}$ & $2.54 \mathrm{D}$ & \\
\hline & \multicolumn{10}{|c|}{ Second season (2014) } \\
\hline Humic acid & $6.44 \mathrm{e}$ & $7.30 \mathrm{~b}$ & $6.36 \mathrm{ef}$ & $6.02 \mathrm{hi}$ & 6.52B & $2.68 b$ & $2.57 \mathrm{de}$ & $2.56 \mathrm{de}$ & $2.32 \mathrm{~h}-\mathrm{j}$ & 2.53B \\
\hline Seaweed extract & $7.04 \mathrm{c}$ & $7.72 \mathrm{a}$ & $6.78 \mathrm{~d}$ & $6.22 \mathrm{fg}$ & $6.94 \mathrm{~A}$ & $2.79 \mathrm{a}$ & $2.65 \mathrm{bc}$ & $2.59 \mathrm{~cd}$ & $2.45 \mathrm{f}^{\circ}$ & $2.62 \mathrm{a}$ \\
\hline Compost tea & $6.02 \mathrm{hi}$ & $6.24 \mathrm{fg}$ & $5.92 \mathrm{i}$ & $5.48 \mathrm{k}$ & $5.90 D$ & $2.52 \mathrm{e}$ & $2.41 \mathrm{fg}$ & $2.36 \mathrm{gh}$ & $2.21 \mathrm{kl}$ & $2.37 \mathrm{D}$ \\
\hline Effective microorganism(EM) & $6.26 f$ & $6.04 \mathrm{~d}$ & $6.10 \mathrm{gh}$ & $5.88 \mathrm{i}$ & $6.22 \mathrm{C}$ & $2.56 \mathrm{de}$ & $2.43 \mathrm{f}$ & $2.40 \mathrm{fg}$ & $2.27 \mathrm{i}-\mathrm{k}$ & $2.41 \mathrm{C}$ \\
\hline Control & 5.121 & $5.72 \mathrm{j}$ & 4.981 & $4.20 \mathrm{~m}$ & $5.00 E$ & $2.33 \mathrm{hi}$ & $2.26 \mathrm{jk}$ & 2.191 & $2.12 \mathrm{~m}$ & $2.22 \mathrm{E}$ \\
\hline Mean & 6.16B & $6.72 \mathrm{~A}$ & 6.02C & $5.56 \mathrm{D}$ & & $2.57 \mathrm{~A}$ & 2.46B & $2.42 \mathrm{C}$ & 2.27D & \\
\hline
\end{tabular}

Means of the same column followed by the same letter were not significantly different according to Duncan MRT at5\% 
Table 5. Effect of some plant biostimulants as soil addition and foliar spray and their interactions on phosphorus and potassium precentage during 2013 and 2014 seasons.

\begin{tabular}{|c|c|c|c|c|c|c|c|c|c|c|}
\hline \multirow{2}{*}{ Treatments } & \multicolumn{5}{|c|}{ Phosphorus\% } & \multicolumn{5}{|c|}{ Potassium\% } \\
\hline & \multicolumn{10}{|c|}{ First season ( 2013) } \\
\hline $\begin{array}{r}\text { Spray (B) } \\
\text { Soil addition (A) }\end{array}$ & $\begin{array}{l}\text { Amino } \\
\text { acid }\end{array}$ & $\begin{array}{c}\text { Seaweed } \\
\text { extract }\end{array}$ & $\begin{array}{l}\text { Gibberellic } \\
\text { acid }\end{array}$ & Control & Mean & $\begin{array}{l}\text { Amino } \\
\text { acid }\end{array}$ & $\begin{array}{l}\text { Seaweed } \\
\text { extract }\end{array}$ & $\begin{array}{c}\text { Gibberellic } \\
\text { acid }\end{array}$ & Control & Mean \\
\hline Humic acid & $0.39 a-e$ & $0.43 \mathrm{ab}$ & $0.37 \mathrm{~b}-\mathrm{f}$ & $0.32 \mathrm{e}-\mathrm{i}$ & $0.37 \mathrm{AB}$ & $1.81 \mathrm{c}-\mathrm{f}$ & $1.86 \mathrm{bc}$ & $1.77 \mathrm{e}-\mathrm{h}$ & $1.73 \mathrm{~h}-\mathrm{k}$ & $1.79 B$ \\
\hline Seaweed extract & $0.42 \mathrm{a}-\mathrm{c}$ & $0.46 \mathrm{a}$ & $0.41 \mathrm{a}-\mathrm{d}$ & $0.36 \mathrm{~b}-\mathrm{g}$ & $0.41 \mathrm{~A}$ & $1.87 \mathrm{~b}$ & $1.93 \mathrm{a}$ & $1.84 \mathrm{~b}-\mathrm{d}$ & $1.79 \mathrm{~d}-\mathrm{g}$ & $1.85 \mathrm{~A}$ \\
\hline Compost tea & $0.34 d-h$ & $0.38 b-f$ & $0.31 \mathrm{f}-\mathrm{i}$ & $0.28 \mathrm{~h}-\mathrm{i}$ & $0.32 \mathrm{C}$ & $1.76 \mathrm{f}-\mathrm{i}$ & $1.80 \mathrm{~d}-\mathrm{g}$ & $1.71 \mathrm{i}-1$ & $1.68 \mathrm{kl}$ & 1.73D \\
\hline Effective microorganism(EM) & $0.36 \mathrm{~b}-\mathrm{g}$ & $0.40 a-d$ & $0.35 \mathrm{c}-\mathrm{h}$ & $0.31 \mathrm{f}-\mathrm{i}$ & $0.35 B C$ & $1.79 \mathrm{~d}-\mathrm{g}$ & $1.82 \mathrm{~b}-\mathrm{e}$ & $1.75 \mathrm{~g}-\mathrm{j}$ & $1.70 \mathrm{j}-1$ & $1.76 \mathrm{C}$ \\
\hline Control & $0.29 \mathrm{~g}-\mathrm{i}$ & $0.31 \mathrm{f}-\mathrm{i}$ & $0.26 \mathrm{i}-\mathrm{j}$ & $0.23 \mathrm{j}$ & $0.27 \mathrm{D}$ & $1.70 \mathrm{j}-1$ & $1.76 \mathrm{f}-\mathrm{i}$ & $1.661 \mathrm{~m}$ & $1.62 \mathrm{~m}$ & $1.68 E$ \\
\hline \multirow[t]{2}{*}{ Mean } & $0.36 \mathrm{~B}$ & 0.39A & $0.34 \mathrm{~B}$ & $0.30 \mathrm{C}$ & & $1.78 B$ & $1.83 \mathrm{~A}$ & $1.74 \mathrm{C}$ & 1.70D & \\
\hline & \multicolumn{10}{|c|}{ Second season (2014) } \\
\hline Humic acid & $0.36 \mathrm{a}-\mathrm{c}$ & $0.37 \mathrm{ab}$ & $0.33 \mathrm{~b}-\mathrm{d}$ & $0.30 \mathrm{de}$ & 0.34A & $1.75 b-f$ & $1.78 \mathrm{a}-\mathrm{d}$ & $1.73 \mathrm{c}-\mathrm{f}$ & $1.69 \mathrm{e}-\mathrm{h}$ & 1.73B \\
\hline Seaweed extract & $0.37 \mathrm{ab}$ & $0.39 \mathrm{a}$ & $0.36 \mathrm{a}-\mathrm{c}$ & $0.32 \mathrm{c}-\mathrm{e}$ & $0.36 \mathrm{~A}$ & $1.82 \mathrm{ab}$ & $1.85 \mathrm{a}$ & $1.80 \mathrm{a}-\mathrm{c}$ & $1.76 b-e$ & $1.80 \mathrm{~A}$ \\
\hline Compost tea & $0.30 \mathrm{de}$ & $0.31 \mathrm{de}$ & $0.28 \mathrm{ef}$ & $0.25 \mathrm{fg}$ & $0.28 B$ & $1.65 \mathrm{~g}-\mathrm{i}$ & $1.72 \mathrm{~d}-\mathrm{g}$ & $1.63 \mathrm{hi}$ & $1.60 \mathrm{ij}$ & $1.65 \mathrm{D}$ \\
\hline Effective microorganism(EM) & $0.31 \mathrm{de}$ & $0.34 b-d$ & $0.30 \mathrm{de}$ & $0.28 \mathrm{ef}$ & $0.30 \mathrm{~B}$ & $1.70 \mathrm{eh}$ & $1.75 b-f$ & $1.68 \mathrm{f}-\mathrm{h}$ & 1.63hi & $1.69 \mathrm{C}$ \\
\hline Control & $0.25 \mathrm{fg}$ & $0.28 \mathrm{ef}$ & $0.24 \mathrm{fg}$ & $0.21 \mathrm{~g}$ & $0.24 \mathrm{C}$ & $1.58 \mathrm{ij}$ & $1.63 \mathrm{hi}$ & $1.54 \mathrm{jk}$ & $1.50 \mathrm{k}$ & $1.56 \mathrm{E}$ \\
\hline Mean & $0.31 \mathrm{AB}$ & 0.33A & 0.30B & $0.27 \mathrm{C}$ & & 1.70B & $1.74 \mathrm{~A}$ & 1.67B & $1.63 \mathrm{C}$ & \\
\hline
\end{tabular}

Means of the same column followed by the same letter were not significantly different according to Duncan MRT at5\% 
Table 6:- Effect of some plant biostimulants as soil addition and foliar spray and their interactions on number of transplants/plant and number of transplants /feddan during 2013 and 2014 seasons.

\begin{tabular}{|c|c|c|c|c|c|c|c|c|c|c|}
\hline \multirow{3}{*}{$\begin{array}{r}\text { Treatments } \\
\text { Spray (B) } \\
\text { Soil addition (A) }\end{array}$} & \multicolumn{5}{|c|}{ Number of transplants/plant } & \multicolumn{5}{|c|}{ Number of transplants /feddan } \\
\hline & \multicolumn{10}{|c|}{ First season ( 2013) } \\
\hline & Amino acid & $\begin{array}{c}\text { Seaweed } \\
\text { extract }\end{array}$ & $\begin{array}{c}\text { Gibberellic } \\
\text { acid }\end{array}$ & Control & Mean & Amino acid & $\begin{array}{c}\text { Seaweed } \\
\text { extract }\end{array}$ & $\begin{array}{l}\text { Gibberellic } \\
\text { acid }\end{array}$ & Control & Mean \\
\hline Humic acid & $90.15 \mathrm{~cd}$ & $91.98 \mathrm{bc}$ & $88.75 \mathrm{de}$ & $85.36 \mathrm{~g}-\mathrm{i}$ & 89.06B & $242710 \mathrm{~cd}$ & $247637 b c$ & $238941 \mathrm{de}$ & $229814 g-i$ & 239776B \\
\hline Seaweed extract & $92.87 \mathrm{ab}$ & $94.35 \mathrm{a}$ & $91.46 \mathrm{bc}$ & $87.29 \mathrm{e}-\mathrm{g}$ & 91.49A & $250033 \mathrm{ab}$ & $254018 \mathrm{a}$ & $246237 \mathrm{bc}$ & $235010 \mathrm{e}-\mathrm{g}$ & 246325A \\
\hline Compost tea & $82.35 \mathrm{jk}$ & $83.56 \mathrm{ij}$ & $80.75 \mathrm{k}$ & 77.941 & 81.15D & $221710 \mathrm{jk}$ & $224968 \mathrm{ij}$ & $217403 \mathrm{k}$ & 2098371 & 218480D \\
\hline Effective microorganism(EM) & $86.18 f-h$ & $87.84 \mathrm{e}-\mathrm{f}$ & 84.66hi & $81.52 \mathrm{jk}$ & $85.05 \mathrm{C}$ & 232022f-h & 236491ef & 227930hi & $219476 \mathrm{jk}$ & $228980 \mathrm{C}$ \\
\hline Control & 78.121 & $80.63 \mathrm{k}$ & 76.401 & $71.14 \mathrm{~m}$ & $76.57 \mathrm{E}$ & 2103221 & $217080 \mathrm{k}$ & 2056911 & $191530 \mathrm{~m}$ & 206156E \\
\hline \multirow[t]{2}{*}{ Mean } & 85.93B & 87.67A & $84.40 \mathrm{C}$ & 80.65D & & 231360B & 236039A & 227240C & 217133D & \\
\hline & \multicolumn{10}{|c|}{ Second season (2014) } \\
\hline Humic acid & $84.98 b-d$ & $87.10 \mathrm{~b}$ & $83.67 \mathrm{de}$ & $82.15 \mathrm{ef}$ & 84.47B & 228791b-d & $234499 b$ & 225264de & 221172ef & 227432B \\
\hline Seaweed extract & $87.25 \mathrm{~b}$ & $89.83 \mathrm{a}$ & $86.19 \mathrm{bc}$ & $84.42 \mathrm{c}-\mathrm{e}$ & $86.92 \mathrm{~A}$ & $234903 b$ & $241849 a$ & $232049 \mathrm{bc}$ & $227283 c-e$ & 234021A \\
\hline Compost tea & $78.19 \mathrm{~g}$ & $80.75 \mathrm{f}$ & $76.25 \mathrm{gh}$ & $72.98 \mathrm{ij}$ & 77.04D & $210510 \mathrm{~g}$ & $217403 f$ & $205287 \mathrm{gh}$ & 196484ij & 207421D \\
\hline Effective microorganism(EM) & $81.13 \mathrm{f}$ & $84.26 \mathrm{c}-\mathrm{e}$ & $80.82 \mathrm{f}$ & 75.25hi & $80.36 \mathrm{C}$ & $218426 f$ & $226853 c-e$ & $217591 \mathrm{f}$ & 202595hi & $216366 \mathrm{C}$ \\
\hline Control & 73.36ij & $76.16 \mathrm{gh}$ & $72.82 \mathrm{j}$ & $68.37 \mathrm{k}$ & $72.68 \mathrm{E}$ & $197507 \mathrm{ij}$ & $205045 \mathrm{gh}$ & $196053 \mathrm{j}$ & $184072 \mathrm{k}$ & $195669 \mathrm{E}$ \\
\hline Mean & $80.98 B$ & 83.62A & $79.95 \mathrm{C}$ & 76.63D & & 218027B & 225130A & 215249C & 206321D & \\
\hline
\end{tabular}

Means of the same column followed by the same letter were not significantly different according to Duncan MRT at5\% 
Table 7:- Effect of some plant biostimulants as soil addition and foliar spray and their interactions on diseases infection percentages during 2013 and 2014 seasons.

\begin{tabular}{|c|c|c|c|c|c|c|c|c|c|c|}
\hline \multirow{3}{*}{$\begin{array}{c}\text { Treatments } \\
\text { Spray }(B)\end{array}$} & \multicolumn{10}{|c|}{ Infection \% } \\
\hline & \multicolumn{5}{|c|}{ First season ( 2013) } & \multicolumn{5}{|c|}{ Second season (2014) } \\
\hline & $\begin{array}{c}\text { Amino } \\
\text { acid }\end{array}$ & $\begin{array}{c}\text { Seaweed } \\
\text { extract }\end{array}$ & $\begin{array}{c}\text { Gibberellic } \\
\text { acid }\end{array}$ & Control & Mean & $\begin{array}{c}\text { Amino } \\
\text { acid }\end{array}$ & $\begin{array}{c}\text { Seaweed } \\
\text { extract }\end{array}$ & $\begin{array}{c}\text { Gibberellic } \\
\text { acid }\end{array}$ & Control & Mean \\
\hline Humic acid & $13.60 \mathrm{~cd}$ & $11.20 \mathrm{f}-\mathrm{h}$ & 12.80de & $15.10 b$ & 13.18B & $11.90 \mathrm{c}$ & $9.70 \mathrm{e}$ & $11.10 \mathrm{~d}$ & $12.60 \mathrm{~b}$ & 11.32B \\
\hline Sea weed extrat & $7.90 \mathrm{i}$ & $6.30 \mathrm{jk}$ & $7.80 \mathrm{i}$ & $10.20 \mathrm{~h}$ & 8.05D & $6.20 \mathrm{i}$ & $4.30 \mathrm{k}$ & $5.50 \mathrm{j}$ & $7.90 \mathrm{gh}$ & 5.97D \\
\hline Compost tea & $12.10 \mathrm{ef}$ & $10.80 \mathrm{gh}$ & $11.50 \mathrm{fg}$ & $13.30 \mathrm{c}-\mathrm{e}$ & 11.93C & $8.70 f$ & $7.40 \mathrm{~h}$ & $8.20 \mathrm{fg}$ & $10.20 \mathrm{e}$ & 8.62C \\
\hline Effective microorganism(EM) & $6.50 \mathrm{j}$ & 2.601 & $5.10 \mathrm{k}$ & $7.40 \mathrm{ij}$ & $5.40 \mathrm{E}$ & $4.10 \mathrm{k}$ & 2.201 & $3.90 \mathrm{k}$ & $5.60 \mathrm{ij}$ & 3.95E \\
\hline Control & $15.70 \mathrm{~b}$ & $13.60 \mathrm{~cd}$ & $14.50 \mathrm{bc}$ & $17.80 \mathrm{a}$ & $15.40 \mathrm{~A}$ & $13.60 \mathrm{a}$ & $11.80 \mathrm{c}$ & $12.40 \mathrm{bc}$ & $14.20 \mathrm{a}$ & 13.00A \\
\hline Mean & 11.16B & 8.90D & $10.34 \mathrm{C}$ & $12.76 \mathrm{~A}$ & & $8.90 \mathrm{~B}$ & 7.08D & 8.22C & 10.10A & \\
\hline
\end{tabular}

Means of the same column followed by the same letter were not significantly different according to Duncan MRT at5\% 


\section{References}

A. O.A. C. 1990. Official and Tentative Methods of Analysis. Association of Official Analytical Chemists. $15^{\text {th }}$ ed. Washington, D.C, U.S.A.

Aberg, B.1961. Nucleceic acids and proteins in plants. Encycl. Plant Physiol., Vol.14, Spriger Verlag, Berlin.

Abo Sedera, F.A., A. A. Abd El-Latif, L.A.A. Bader and S. M. Rezk.2010. Effect of NPK mineral fertilizer levels and foliar spray with humic and amino acids on yield and quality of strawberry. Eypt. J. of Appl. Sci., 25(4):154-169.

Abo Sedera, F.A., L.A. Bader, A. A. Abd El-Latif and S. M. Rezk.2014. Effect of mineral N, P plus $\mathrm{P}$ Bio-fertilizer levels and foliar spray with calcium and seaweed extract on strawberry productivity. J. Biol. Environ.Sci.,9(3):343-366.

Allahverdiyev,S.R., E.Kirdar, G.Gunduz, D.Kadimaliyev, V. Revin, V. Filonenko, D.A.Rasulova, Z.I. Abbasova,S.I.Ganizade and E.M.Zeynalova.2011. Effective microorganisms (EM) technology in plants. Technology 14:103106.

Berlyn, G.P. and R.O. Russo. 1990. The use of organic biostimulants to promote root growth. Below ground Ecol., 2:12-13.

Blunden, G., T. Jenkins and Y.W. Liu. 1997. Enhanced leaf chlorophyll levels in plants treated with seaweed extract. J. Appl. Phycol., 8:535-543.

Brown, J. and O. Lilleland. 1946. Rapid determination of potassium and sodium in plant material and soil extracts by flame photometric. Proc. Amer. Soc. Hort. Sci., 48: 341- 346.

Dhingra,O.D. and J.B.Sinclair.1995. Basic plant pathology methods. Lewis Publishers (Boca Raton), London, pp.343.

Fayek, M. A., T.A. Fayed, E.M. Fakhrani and N.S. Shaymmaa, 2014. Yield and fruit quality of " Le-conte" pear trees as affected by compost tea and some antioxidants applications. J. of Hort. Sci. \& Ornamental plants 6(1): 01-08.

Hytonen, T., P. Elomaa,T. Moritz and O.Junttila.2009. Gibberellin mediates daylengthcontrolled differentiation of vegetative meristems in strawberry (Fragaria $x$ ananassa Duch). BMC plant Biology: 9-18

Jameson, P.E. 1993. Plant hormones in the algae. Progress in Phycological Research. 9: 239-245.

Jennifer, C.H., M. Sina Adl and P.R.Warman.2009. Are compost teas an effective nutrient amendment in the cultivation of strawberries? Soil and plant Tissue Effects. J.Sci. Food Agric.,89:390-397.

John, M.K. 1970. Colorimetric determination of phosphorus in soil and plant material with ascorbic acid. Soil Sci., 109: 214-220.

Khalid, S., K.M.Qureshi, I.A.Hafiz, K.S. Khan and U.S.Qureshi.2013. Effect of organic amendments on vegetative growth, fruit and yield quality of strawberry. Pakistan J.Agric.Res. 26(2):104-112.

Ozdemir, E., N.Kaska, K. Gunduz and S. Serce.2009. Strawberry runner tip production on open field for plug plants. Horticulture, Environment and Biotechnology, 50(1):3-8.

Pane,C., G.Celano, D.Villecco and M.Zaccardelli.2012. Control of Botrytis cinerae, Alterrnaria alternate and Pyrenochaeta lycopersici on tomato with compost-tea applications. Crop protection 38:80-86.

Pregl, E. 1945. Quantitative organic micro analysis. $4^{\text {th }}$ Ed. J. Chundril, London.

Ragab, M. E. 1996. Effect of $\mathrm{GA}_{3}$ on number and some transplants characters of strawberry nurseries. Fourth Arabic Conf., Minia, Egypt. pp.91-99.

Ragab, M.E, A.E.Omran, S.M.Youssef and W.M.Sabt. 2010. Effect of some application and agricultural practices on runner formation and transplant production in strawberry nurseries.J.Biol.Chem. Environ.Sci.,5(4):247261.

Rosalba, M.H., S.R. Fernando and G.H. Jeffrey.2013. Effect of liquid seaweed extract on growth of tomato seedlings. J. Appl.Phycol.,2: 21-29.

Scheuerell, S.J. and W. F. Mahaffee.2004. Compost tea as container medium drench for suppressing seedling damping off caused by Pythium ultimum. Phytopathol., 94:1156-1163.

Shafshak, N.S, S.M. Eid, F.A. Abo Sedera and M.H.M.Mohamed.2011. Improving growth and productivity of strawberry via soil addition and foliar application of some safety growth stimulating compounds. Annals of Agric. Sci., Moshtoher, 49(2):153-162.

Shehata, S.A., A.A.Gharib, M.M.El-Mogy, K.F.Abdel Gawad and E.A.Shalaby.2011. Influence of compost, amino and humic acids on the growth, and yield and chemical parameters of strawberries. J.of Medicinal Plants Res.,5(11):2304-2308.

Snedecor, G. W. and W.G. Cocharn. 1991. Statistical methods. $8^{\text {th }}$ E.d., lowa State Univ. press, Lowa. USA. 


\section{تأثير بعض منشطات النمو على إنتاج وجودة شتتلات الفراولة \\ مصطفى حمزة محمد محمد

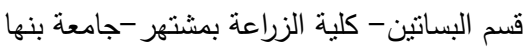

أجريت تجربتان حقليتان بمزرعة خاصة مركز شبين القناطر بمحافظة القليوبية خلا موسمي 2013- 2014 لدراسة تأثثر الإضافة الأرضية لكلا من حمض الهيوميك بمعدل 5 جرام/النبات ومستخلص الطحالب البحرية بمعدل 5 مل/النبات وشاى الكمبوست بمعدل 10مل/النبات والكائنات النافعة بمعدل 5مل/النبات وكذلك الرش بكلا من الأحماض الامينية 2مل/لتز ومستخلص الطحالب البحرية 2مل/لتز وحمض الجبريلليك بتركيز 50 جزء في المليون بالإضافة إلى معاملة الكنترول والتفاعل بينهما علي النمو الخضري والتركيب الكيماوي وإنتاجية وجودة شتلات الفراولة من صنف فيستيفال. وقد أوضحت النتائج أن الإضافة الأرضية لمستخلص الطحالب البحرية بمعدل5مل/للنبات ثناث مرات خلال موسم النمو وذلك بعد أسبوعين من الشتل وعلى فترات كل أسبوعين مقترنة برش النباتات بمستخلص الطحالب البحرية بمعدل 2مل/لتر ستة مرات بعد 30 يوم من الشتل وعلى فترات كل 15يوم إلى الحصول علي أفضل عدد من المدادات الرئيسية وعدد الأوراق/الثنلة و اكبر سمك للتاج واكبر عدد للجذور وزيادة

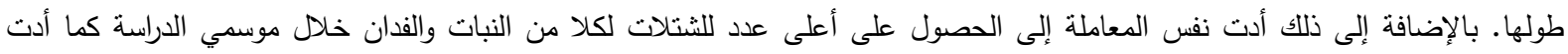
الإضافة الأرضية والرش بمستخلص الطحالب إلى الحصول على أعلى محتوى من الكربوهيدات والفوسفورو البوتاسيوم في أنسجة الشتلات بينما

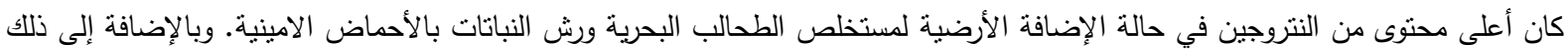

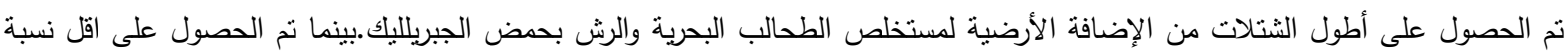
إصابة للشتلات من الإضافة الأرضية للكائنات النافعة الدقيقة (EM) والرش بمستخلص الطحالب البحرية خلال موسمي الدراسة.

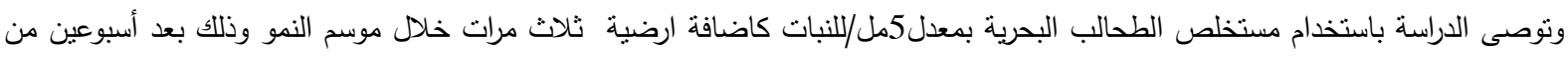
الثتل وعلى فترات كل أسبوعين مقترنة برش النباتات بمستخلص الطحالب البحرية بمعدل 2مل/لتر او الاحماض الامينية ستة مرات بعد 30 يوم

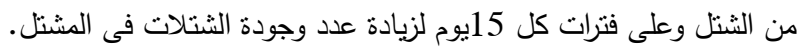

